\title{
PENGARUH RESPONSIVENESS PERAWAT DALAM PRAKTIK KOMUNIKASI TERAPEUTIK TERHADAP KEPUASAN PASIEN INSTALASI RAWAT INAP RSU HAJI SURABAYA
}

\author{
The Effect of Nurse's Responsiveness in Therapeutic Communication Practice to In- \\ Patients' Satisfaction at Haji Surabaya Hospital
}

Ajenk Saprilla Nanda

PERSAKMI Surabaya, Indonesia

E-mail: ajenk.nanda.saprilla-2014@fkm.unair.ac.id

\begin{abstract}
Background: Patient's satisfaction is one of indicators measured in the hospital minimum service standards. In Installation of Inpatient (IRNA) of Haji Surabaya hospital, there are 17 indicators, but only nine are met (52.94\%). One of them is patients' satisfaction level amounted to $74.35 \%$ out of the standard (82\%). The high number of complaints on nurses' competence in providing services causes the unachieved patients' satisfaction. There were 61 complaints from 2014 to 2017.

Aim: This study aimed to analyze the influence of nurses' responsiveness to patients' satisfaction of in-patient installation (IRNA) at Haji Surabaya Hospital.

Method: The questionnaires used Likert scale 1-5 for independent variables and dependent variables. The scoring scales for the independent variable or nurses' responsiveness range from strongly disagree to strongly agree. Meanwhile, the scoring scale for the dependent variable ranges from very dissatisfied to very satisfied.

Results: The findings indicated that there was a significant influence of responsiveness on patients' satisfaction amounted to $0.003(<\alpha=0.05)$. This indicated that the better assessment on the nurses' responsiveness is, the more satisfied the patients are at in-patient installation (IRNA), Haji Surabaya Hospital.

Conclusion: It can be concluded that more than 20\% of responses was satisfied with the nurses' responsiveness. The hospital needs to hold a human resource training especially a nurse-patient therapeutic communication training for maintaining the service quality at the hospital.
\end{abstract}

Keywords: hospitalization, patient, responsiveness, satisfaction

\section{ABSTRAK}

Latar Belakang: Kepuasan pasien merupakan salah satu indikator yang diukur dalam Standar Pelayanan Minimum Rumah Sakit. Pada Instalasi Rawat Inap (IRNA) Rumah Sakit Umum Haji Surabaya terdapat 17 indikator namun hanya 9 yang terpenuhi $(52,94 \%)$. Salah satunya adalah kepuasan pasien dengan capaian sebesar $74,35 \%$ dari standar yang ditetapkan rumah sakit sebesar $82 \%$. Salah satu penyebab belum tercapainya kepuasan pasien tersebut adalah masih tingginya angka keluhan pasien terhadap aspek kompetensi perawat dalam memberikan pelayanan sejumlah 61 keluhan selama tahun 2014-2017.

Tujuan: Penelitian ini bertujuan untuk menganalisis pengaruh daya tanggap atau responsiveness perawat terhadap kepuasan pasien Instalasi Rawat Inap (IRNA) Rumah Sakit Umum Haji Surabaya.

Metode: Instrumen kuesioner penelitian ini menggunakan skala likert 1-5 pada variabel bebas dan variabel terikat. Skala penilaian pada variabel bebas atau responsiveness perawat berkisar mulai dari sangat tidak setuju sampai sangat setuju. Sedangkan, skala penilaian untuk variabel terikat berkisar mulai dri sangat tidak puas sampai sangat puas.

Hasil: Berdasarkan hasil penelitian dapat disimpulkan bahwa terdapat pengaruh signifikan daya tanggap atau responsiveness sebesar $0,003(<\alpha=0,05)$ terhadap kepuasan pasien. Hal ini menunjukkan semakin bagus penilaian pasien terhadap daya tanggap atau responsiveness perawat maka akan semakin meningkatkan kepuasan pasien di Instalasi Rawat Inap (IRNA) Rumah Sakit Umum Haji Surabaya.

Kesimpulan: Lebih dari $20 \%$ penilaian responden berada dalam kategori puas terhadap ketanggapan perawat. Rumah sakit tersebut perlu untuk mengadakan pelatihan Sumber Daya Manusia khususnya pelatihan komunikasi terapeutik antara perawat-pasien untuk menjaga kualitas pelayanan di rumah sakit tersebut.

Kata Kunci : kepuasan, komunikasi terapeutik, pasien rawat inap, responsiveness

Received: 4 May $2018 \quad$ Accepted: 20 August $2018 \quad$ Published: 1 December 2018 


\section{PENDAHULUAN}

Manajemen mutu dalam bidang organisasi penyedia jasa pelayanan kesehatan saat ini menjadi isu penting karena terjadi perubahan permintaan masyarakat, kebijakan pemerintah, pola epidemiologi penyakit, dan persaingan antar organisasi penyedia jasa pelayanan kesehatan. Organisasi penyedia jasa pelayanan kesehatan yang tidak mampu memenuhi perubahan tersebut maka akan ditinggalkan oleh pelanggannya. Oleh karena itu pembahasan terkait manajemen mutu menjadi penting, salah satunya berguna untuk mempertahankan kepercayaan pasien dengan terus berupaya meningkatkan pelayanan sehingga kepuasan pelanggan juga akan meningkat. Kepuasan didefinisikan sebagai suatu upaya pemenuhan kebutuhan pelanggan yang berkaitan dengan terpenuhinya harapan-harapan pelanggan terhadap produk atau jasa yang diterima (Easter, Wowor, and Pondaag, 2017). Kepuasan merupakan suatu hal yang bersifat subyektif. Terdapat berbagai faktor yang dapat menyebabkan pelanggan tidak puas salah satunya adalah responsiveness perawat dalam melakukan pelayanan yang membutuhkan waktu lama (Eninurkhayatun, Suryoputro and Fatmasari, 2017).

Rumah Sakit Umum Haji Surabaya didirikan pada tanggal 17 April 1993 merupakan rumah sakit tipe B Non Pendidikan dengan SK Menkes No. 1006/Menkes/SKIX/1998. Rumah Sakit Umum Haji Surabaya mempunyai tugas pokok untuk memberikan pelayanan kesehatan perorangan secara paripurna meliputi pelayanan pengobatan serta pemulihan kesehatan sesuai dengan standar pelayanan rumah sakit. Oleh karena itu, manajemen RSU Haji Surabaya pun dituntut untuk terus berbenah mengikuti perubahan dan perkembangan ilmu pengetahuan dan teknologi guna mempertahankan pelanggan (RSUD Haji Surabaya, 2017)

Berdasarkan data Laporan Kinerja Tahun 2017 terdapat 302 indikator SPM RSU Haji Surabaya dengan realisasi capaian sebesar 70,86\% dari target yang ditetapkan sebesar $88,00 \%$. Terdapat 29 unit kerja yang belum memenuhi standar capaian indikator SPM, salah satunya adalah Instalasi Rawat Inap (IRNA) yang hanya memenuhi 9 dari 17 indikator atau sekitar 52,94\%.

Terdapat 8 indikator yang belum dipenuhi oleh instalasi rawat inap RSU Haji Surabaya, salah satunya adalah indikator kepuasan pasien sebesar $74,35 \%$ dari standar yang telah ditetapkan sebesar $82,00 \%$. Kepuasan merupakan suatu hal yang bersifat subyektif karena setiap individu akan mempunyai penilaiannya sendiri terhadap jasa pelayanan yang diterima. Terdapat berbagai faktor yang dapat mempengaruhi tingkat kepuasan pasien. Salah satunya dapat disebabkan oleh peningkatan jumlah kunjungan pasien yang akan berdampak pada kualitas pelayanan kesehatan yang diberikan provider kepada pasien. Hal ini dapat disebabkan karena waktu pelayanan terbatas atau tetap sedangkan beban kerja provider tinggi yang akan berdampak pula pada kepuasan pasien terhadap pelayanan yang diterima.

Terdapat 15 indikator pencapaian sasaran mutu Instalasi Rawat Inap Rumah Sakit Umum Haji Surabaya diantaranya pemberi pelayanan di IRNA adalah dokter spesialis ; perawat berijizah minimal D-3 ; terdapat dokter penanggung jawab ; kematian pasien $\geq 48$ jam ; kejadian dikubitus ; kejadian phlibitis ; angka kejadian infeksi nosokomial ; tingkat kesembuhan pasien diare dalam 3 haru ; tidak adanya pasien jatuh dari tempat tidur ' tidak adanya pasien jatuh dari kamar mandi ; ketepatan waktu visite dokter ; kejadian pasien pulang paksa ; tercapainya penyelesaian komplain ; dan Indeks Kepuasan Masyarakat (koordinasi dengan Litbang). terdapat 4 indikator pencapaian sasaran mutu Instalasi Rawat Inap Rumah Sakit Umum Haji Surabaya yang belum tercapai, salah satunya adalah Indeks Kepuasan Masyarakat (IKM) pada tahun 2017 sebesar 73,14\% dari standar yang ditetapkan sebesar $85,00 \%$. Berdasarkan data diketahui bahwa penyebab belum tercapainya standar kepuasan pasien di Instalasi Rawat Inap salah satunya disebabkan oleh faktor tenaga kesehatan yang menyebabkan timbulnya keluhan pasien terhadap aspek pelayanan (responsiveness) dan keramahan petugas kesehatan dalam hal ini adalah perawat.

Aspek responsiveness berkaitan dengan daya tanggap tenaga kesehatan rumah sakit dalam hal ini dokter, perawat, atau tenaga medis lain untuk segera datang melayani saat diperlukan oleh pasien. Daya tanggap juga dapat berkaitan dengan tenaga kesehatan mengunjungi ruang inap pasien untuk menawarkan bantuan atau menanyakan kondisi pasien tanpa diminta (Supriyanto and Ernawaty, 2010). Berdasarkan hasil wawancara dengan Kepala Bagian Humas Rumah Sakit Umum Haji Surabaya, terdapat 4 faktor utama yang dikeluhkan pasien terkait dengan pelayanan perawat diantaranya seperti perawat dinilai kurang ramah (lupa memberikan salam kepada pasien), pelayanan yang diberikan perawat terkadang dinilai kurang memberi rasa nyaman kepada pasien (pada saat memberikan tindakan penyuntikan), perawat kurang dalam memberikan penjelasan terkait tindakan yang akan diberikan kepada pasien, serta perawat masih dinilai kurang tanggap dalam memberikan pelayanan kepada pasien (saat pasien meminta bantuan, perawat tidak segera datang).

Penanganan keluhan pasien terhadap aspek responsiveness merupakan salah satu bentuk kepedulian rumah sakit untuk selalu berbenah dengan memberikan pelayanan yang terbaik. Penanganan keluhan yang baik akan memberikan peluang untuk mengubah pasien yang tidak puas menjadi puas atau bahkan meningkat menjadi pasien loyal. Sehingga menjadi suatu keharusan bagi pihak manajemen rumah sakit untuk melakukan evaluasi guna mengetahui faktor penyebab sehingga selanjutnya dapat melakukan upaya perbaikan. ('Laporan kinerja blud rumah sakit umum haji surabaya tahun 2017', 2017) Selain itu, penanganan keluhan juga akan memberikan peluang untuk mengubah pasien yang tidak puas 
menjadi puas atau bahkan meningkat menjadi pasien loyal.

\section{METODE}

Penulisan artikel ilmiah ini menggunakan metode penelitian analitik untuk mencari pengaruh variabel independen terhadap variabel dependen dengan rancang bangun penelitian cross sectional study. Penelitian dilakukan pada bulan April 2018 di gedung Shofa dan Marwah Instalasi Rawat Inap RSU Haji Surabaya. Populasi dalam penelitian ini adalah seluruh pasien yang mendapatkan pelayanan pada Instalasi Rawat Inap RSU Haji Surabaya pada tahun 2017 dalam satu bulan ratarata terdapat sebesar 1.212 pasien. Perhitungan sampel dilakukan secara probability sampling dengan menggunakan teknik simple random sampling menggunakan rumus Lemeshow diperoleh sejumlah 69 pasien. Sampel penelitian adalah pasien instalasi rawat inap RSU Haji Surabaya yang berusia lebih dari sama dengan 18 tahun $(\geq 18$ tahun), mampu diajak berkomunikasi secara sadar, dan berkenan untuk menjadi responden penelitian dengan menandatangani informed consent yang disediakan oleh peneliti.

Teknis analisis data pada penelitian terdiri dari 3 tahap analisis yaitu analisis deskriptif yang dilakukan untuk mendeskripsikan faktor terkait karakteristik individu pasien yang bersedia menjadi responden dalam penelitian meliputi umur, jenis kelamin, pendidikan, pekerjaan, status perkawinan, dan jenis pembayaran pasien. Selanjutnya, distribusi penilaian pasien terhadap variabel responsiveness pada skala 5 mendapat nilai $\leq 20 \%$ maka dapat disimpulkan sebagai isu strategis. Analisis kedua yaitu analisis inferensial yang dilakukan karena penelitian ini bertujuan untuk mengetahui pengaruh variabel independen terhadap variabel dependen sehingga dilakukan analisis uji statistik. Variabel independen dalam penelitian ini adalah responsiveness perawat. Sedangkan variabel dependen dalam penelitian ini adalah kepuasan pasien. Uji pengaruh variabel independen terhadap variabel dependen menggunakan uji regresi linier berganda. Selanjutnya dilakukan interpretasi isu strategis yang perlu diperbaiki diperoleh berdasarkan uji pengaruh variabel responsiveness terhadap variabel kepuasan yang menunjukkan nilai signifikansi < 0,05 (signifikan) dan analisis deskriptif untuk setiap pertanyaan dalam komponen responsiveness yang mendapat penilaian pasien pada skala $5 \leq 20 \%$. Interpretasi isu strategis ini berdasarkan pada prinsip pareto (pareto principle). Prinsip Pareto dikemukakan oleh seorang ahli ekonomi-sosiologi Italia bernama Alfredo Pareto pada tahun 1906. Alfredo Pareto adalah seorang Profesor dibidang Ekonomi Politik di Lausanne, Swiss. Prinsip Pareto dikenal juga dengan berbagai istilah seperti The Principle of Least Effort dan The Principle of Imbalance. Prinsip Pareto (Pareto Principle) bermula pada tahun 1906, Alfredo Pareto mengamati bahwa $80 \%$ dari pendapatan di Italia dimiliki oleh $20 \%$ dari jumlah populasi penduduk
Italia. Oleh karena itu prinsip pareto dikenal juga sebagai aturan 80:20 yang mempunyai arti bahwa $20 \%$ dari masalah mempunyai $80 \%$ dari dampak serta hanya $20 \%$ dari masalah yang ada yang dianggap penting sehingga sisanya dianggap sebagai masalah yang mudah. Prinsip pareto tersebut kemudian dikembangkan oleh seorang ahli manajemen bisnis bernama Joseph $\mathrm{M}$. Juran yang dikenal dengan "Asumsi Juran" sebagai instrumen untuk mengklasifikasi masalah-masalah terkait kualitas dalam organisasi manufaktur dan jasa. Prinsip utama dalam aturan 80:20 pareto ini adalah bahwa dengan memaksimalkan $20 \%$ usaha maka akan memberikan hasil $80 \%$ secara maksimal. Dalam implementasinya, prinsip pareto tersebut juga dapat diterapkan di berbagai hal diantaranya seperti $80 \%$ dari keluhan pelanggan muncul dari $20 \%$ dari produk atau jasa yang diberikan; $80 \%$ dari output yang dihasilkan diperoleh dari $20 \%$ masukan; $20 \%$ dari cacat sistem akan menyebabkan $80 \%$ masalah; serta $20 \%$ dari memaksimalkan produk atau jasa maka akan mencapai $80 \%$ dari keuntungan.

Prinsip pareto adalah suatu model perbandingan yang sangat luas digunakan, tidak terkecuali pada pelayanan kesehatan. Terdapat skala 1-5 pada kuesioner penelitian yang selanjutnya akan dijumlah pada masing-masing variabel untuk setiap responden.

\section{HASIL DAN PEMBAHASAN}

\section{Daya Tanggap atau Responsiveness}

Daya tanggap atau responsiveness didefinisikan sebagai suatu bentuk keinginan atau kemauan yang dilakukan secara sadar oleh seseorang untuk membantu dan memberikan jasa (Luan et al., 2018). Daya tanggap adalah suatu kemauan untuk membantu dan memberikan pelayanan yang cepat (responsif), tepat, dan penyampaian informasi secara jelas kepada pelanggan. Daya tanggap atau responsiveness tenaga kesehatan dalam hal ini perawat dalam praktik komunikasi terapeutik dapat meliputi 5 hal dasar seperti; perawat segera datang ketika pasien membutuhkan; perawat secara berkala mengunjungi pasien tanpa diminta; perawat segera menawarkan bantuan tanpa diminta ketika pasien kesulitan melakukan sesuatu hal; perawat akan aktif bertanya kepada pasien mengenai hal-hal yang perlu dibantu; dan perawat tanggap dalam melakukan pelayanan atau perawatan terhadap pasien (Supriyanto Ernawaty, 2010).

Selain kelima hal dasar daya tanggap atau responsiveness tersebut di atas, daya tanggap mencakup hal yang lebih luas lagi terkait mutu pelayanan jasa bidang kesehatan. Indikator daya tanggap atau responsiveness meliputi kesanggupan perawat untuk membantu serta menyediakan pelayanan secara paripurna seperti; perawat mampu memberikan respon yang cepat di setiap pelayanan yang diberikan; perawat mampu bertindak secara sigap; perawat seharusnya memberikan kesempatan kepada pasien untuk bertanya terkait informasi atau kondisi 
kesehatannya; perawat memperhatikan kebutuhan serta keluhan pasien; serta perawat bersikap sopan dan ramah kepada pasien untuk menjalin komunikasi 2 arah yang bertujuan untuk kesembuhan pasien (therapeutic communication) (Khumayrah, 2015)

Daya tanggap atau responsiveness merupakan penilaian mutu yang paling dinamis. Hal ini dikarenakan penilaian setiap individu cenderung akan berbeda antara satu pasien dengan pasien lain terkait standar ketanggapan petugas kesehatan dalam memberikan jasa pelayanan sesuai dengan prosedur. Daya tanggap merupakan persepsi pasien terhadap kemampuan dan kehandalan perawat untuk tanggap dan sigap terhadap berbagai hal termasuk keluhan maupun keperluan pasien.

\section{Komunikasi Terapeutik}

Komunikasi didefinisikan sebagai proses interpersonal yang melibatkan dua orang atau lebih serta mengandung unsur komunikasi verbal dan non verbal. Unsur komunikasi ini berfungsi menerjemahkan informasi, ide, atau gagasan yang hendak disampaikan. Tujuan dari komunikasi adalah penyampaian informasi dari pengirim (sender) ke penerima (receiver) melalui suatu media. Informasi yang disampaikan tersebut dapat diterima secara utuh atau bahkan hilang sebagian karena adanya faktor-faktor pengganggu seperti tidak adanya elemen-elemen dasar komunikasi.

Elemen-elemen dasar komunikasi meliputi; Referen (Referent) merupakan sesuatu hal yang dapat memotivasi individu untuk melakukan proses komunikasi dengan individu lain; Pengirim (sender) merupakan individu yang akan menyampaikan pesan berupa informasi, ide, atau gagasan. Pengirim juga harus memahami ketepatan isi pesan serta emosi yang terdapat dalam pesan yang hendak disampaikan; Dapat disebut pula dengan encoder, pesan (Message) merupakan informasi, ide, atau gagasan yang hendak disampaikan mengandung makna verbal, non verbal, dan simbolik; Media (Channel) merupakan alat penyampaian dan penerimaan pesan yaitu indera penglihatan dan pendengaran; Penerima (Receiver) disebut juga decoder merupakan individu atau pihak lain yang menerjemahkan kode pesan yang disampaikan oleh sender; Serta umpan balik (Feedback) merupakan proses hubungan interaksi timbal balik atau pengembalian pesan dari penerima ke pengirim (Potter and Perry, 2010). Elemen ini sebagai indikator bahwa pesan yang telah disampaikan sebelumnya oleh pengirim dapat diterima dengan baik dan dipahami maknanya oleh penerima.

Proses komunikasi terjadi dimanapun dan kapan saja, tidak terkecuali dalam bidang kesehatan. Komunikasi yang intens akan terjalin antara pasien dengan petugas kesehatan terutama pada pasien rawat inap. Hal ini dikarenakan pasien berada lebih dari 24 jam di suatu ruang perawatan yang membutuhkan bantuan asuhan keperawatan secara berkesinambungan. Komunikasi yang efektif merupakan salah satu unsur terpenting dalam praktik keperawatan. Kemampuan atau keahlian berkomunikasi secara efektif merupakan bagian dari standar pembangunan dan pemeliharaan lingkungan kerja yang sehat. Komunikasi efektif adalah suatu alat mencapai helping-healing relationship antara pasien dengan perawat (Kusmiran, 2017).

Teori terkait komunikasi interpersobal perawat dengan pasien dikenal dengan Hildegard Peplau's Theory of Nurse-Client Relationship yang dikemukakan oleh Hildegard Peplau. Teori tersebut memandang proses asuhan keperawatan sebagai proses interaktif dan kolaboratif antara pasien dan pasien. Hubungan perawat dan pasien dimulai dengan terjadinya perubahan status kesehatan pada pasien serta adanya ketersediaan perawat dengan kemampuan dalam memberikan asuhan keperawatan. Pasien dengan beragam karakteristiknya secara tidak langsung menjadi tantangan tersendiri bagi perawat dalam menyesuaikan diri dengan perannya saat berkomunikasi. Perawat harus mampu mengenali, menerima, dan mendorong proses penyembuhan pasien.

Komunikasi terapeutik merupakan bentuk komunikasi interpersonal antara pasien dengan perawat sehingga keduanya akan memperoleh pengalaman untuk saling belajar bersama (Paju Dwiantoro, 2018). Komunikasi terapeutik didefinikasikan sebagai suatu bentuk komunikasi yang dilakukan oleh petugas kesehatan dengan pasien atau dapat pula antar petugas kesehatan dengan tujuan mencapai kesembuhan pasien. Komunikasi terapeutik merupakan suatu proses respons spesifik yang mendorong ekspresi perasaan, ide, serta penyampaian penerimaan dan penghargaan (Potter and Perry, 2010). Proses tersebut berfokus pada pasien namun direncanakan dan diarahkan oleh tenaga kesehatan (Damaiyanti, 2010). Proses komunikasi terapeutik sebagai proses penyampaian kerahasiaan karena pasien mengetahui segala informasi yang diberikan oleh perawat sebagai bahan rekam medis yang tidak boleh diketahui orang lain atau orang yang tidak berwenang. Komunikasi terapeutik mempermudah perawat dalam menjalin hubungan saling percaya dengan pasien sehingga perawat lebih efektif dalam melakukan asuhan keperawatan.

Disamping itu dengan komunikasi terapeutik pasien akan merasa terbantu dalam memperjelas dan memahami kondisi kesehatannya sehingga akan berkurang perasaan ragu, cemas, dan takut terkait kondisi dan segala tindakan penyembuhan yang akan atau sedang diterima. Selain itu dapat pula mengidentifikasi, mengungkapkan perasaan, dan mengkaji masalah serta mengevaluasi tindakan yang dilakukan oleh perawat, membantu pasien dalam mengambil keputusan tindakan, serta mempengaruhi pasien dalam mengambil keputusan tindakan (Damaiyanti, 2010).

Selain itu dengan adanya praktik komunikasi terapeutik yang bertujuan memberikan service excellent maka akan berdampak pada keberlangsungan suatu organisasi penyedia jasa pelayanan kesehatan. Hal ini dikarenakan pasien akan merasa puas dan terbantu sehingga loyalitas 
pasien dapat ditingkatkan (Supriyanto and Ernawaty, 2010). Salah satu indikator dari komunikasi terapeutik adalah daya tanggap atau responsiveness.

Terdapat lima fase komunikasi terapeutik menurut Hildegard Peplau yaitu fase orientation, fase identification, fase exploitation, fase resolution, dan fase termination. Kelima fase tersebut penting dipahami oleh perawat dalam praktik komunikasi terapeutik untuk mencapai kesembuhan dan kepuasan pasien.

Pada fase orientation pasien mulai mengenali atau mengetahui kebutuhan akan pertolongan perawat; sumber daya yang disediakan secara terbatas dapat diterima oleh pasien; serta akan terjadi proses inisiasi hubungan perawat dengan pasien. Pada fase identification pasien memiliki pengetahuan terbatas terkait kebutuhan asuhan keperawatan untuk menangani masalah atau keluhan yang dirasa serta mulai tampak kepercayaan pasien pada keterampilan dan pengetahuan perawat. Pada fase exploitation terjadi peningkatan kepercayaan dan kenyamanan pasien terhadap perawat; pasien dapat memanfaatkan pelayanan yang diberikan oleh perawat; serta terjadi proses penggabungan pengalaman belajar antara perawat dan pasien. Pada fase resolution telah terpenuhinya tujuan awal antara perawat dan pasien sehingga pasien merasa aman; mulai membentuk tujuan baru yang ingin dicapai; serta terjadi peningkatan kemandirian dan penurunan ketergantungan pasien terhadap perawat. Pada fase termination pasien dan perawat mengevaluasi secara bersama-sama hal-hal yang telah dilakukan guna mencapai penyembuhan sehingga perawat dan pasien akan mulai mengakhiri hubungan keduanya.

Berdasarkan Supriyanto dan Ernawaty (2010) dalam bukunya yang berjudul "Pemasaran Industri Jasa Kesehatan" selain responsiveness, terdapat juga 3 indikator lain yang menjadi elemen dalam komunikasi terapeutik yaitu diantaranya attending skill yaitu indikator yang terkait dengan penampilan secara utuh baik fisik maupun psikologis tenaga kesehatan (dokter atau perawat) ketika sedang berkomunikasi dengan pasien maupun keluarga pasien. Attending skill dapat diidentifikasi berdasarkan akronim SOLER, yaitu $S$ - Sit Facing the Client atau Squarely, postur tersebut akan memberikan kesan bahwa perawat bersedia mendengarkan dan tertarik untuk terus mendengarkan, memberi tanggapan, dan umpan balik pada topik pembicaraan pasien ; O - Observe an Open posture, postur tersebut akan memberikan kesan bahwa perawat memiliki sifat terbuka terhadap topik pembicaraan pasien dengan tidak melipat kaki atau tangan maupun berkacak pinggang saat proses komunikasi berlangsung ; $L$ Lean Toward the Client, penampilan fisik yang menunjukkan kesan bahwa perawat mempunyai keinginan untuk mengatakan atau mendengar sesuatu dari pasien ; E - Establish and Maintain Intermittent Eye atau Eye Contact, tidak adanya kontak mata antara perawat dengan pasien saat proses komunikasi berlangsung akan menimbulkan kesan bahwa perawat kurang atau tidak tertarik pada topik pembicaraan. Kontak mata menunjukkan bahwa perawat menghargai pasien ; $\mathrm{R}$ - Relax, perawat harus mampu mengontrol keseimbangan antara ketegangan dan rasa yaman dalam memberi respons serta tindakan kepada pasien. Indikator kedua adalah Respect yang terkait dengan sikap dan perilaku hormat tenaga kesehatan terhadap pasien yang meliputi keramahtamahan dan kesopanan saat proses komunikasi berlangsung. Indikator selanjutnya yaitu Empathy yang terkait dengan sikap dan perilaku tenaga kesehatan untuk bersedia mendengarkan, mengerti, memahami, dan memperhatikan pasien lebih dalam. Perawat bersedia mendengarkan keluhan pasien dan membantu untuk mengurangi atau menyembuhkan keluhannya.

Terdapat beberapa prinsip komunikasi terapeutik seperti komunikasi harus ditandai dengan sikap saling menerima, percayam dan menghargai; perawat harus mampu menciptakan suasana yang memungkinkan pasien bebas berkembang tanpa rasa cemas dan pasien termotivasi untuk mengubah dirinya menjadi lebih baik; perawat harus mampu memahami empati sebagai tindakan terapeutik sedangkan simpati bukan sebagai tindakan terapeutik; perawat harus mengenal dirinya sendiri dan memahami nilai yang dianut; perawat harus menyadari pentingnya kebutuhan fisik maupun mental pasien; serta kejujuran dan keterbukaan adalah aspek utama dalam praktik komunikasi terapeutik.

$$
\text { Analisis pengaruh responsiveness }
$$
menggunakan uji statistik regresi linier sederhana. Selain itu, analisis menggunakan regresi linier dapat pula digunakan sebagai permodelan dengan situasi terdapat variabel yang dipengaruhi dan yang mempengaruhi. Varibael bebas (independent variable) dalam penelitian ini adalah responsiveness atau daya tanggap perawat yang dinotasikan dengan Y. Sedangkan variabel terikat (dependent variabel) penelitian ini adalah kepuasan pasien yang dinotasikan dengan $X$.

Instrumen kuesioner penelitian ini menggunakan skala likert 1-5 pada variabel bebas dan variabel terikat. Skala penilaian pada variabel bebas atau responsiveness perawat yaitu $1=$ sangat tidak setuju ; 2 = tidak setuju ; $3=$ kurang setuju ; 4 = setuju ; 5 = sangat setuju sedangkan skala penilaian pada variabel terikat atau kepuasan pasien yaitu 1 = sangat tidak puas ; 2 = tidak puas ; $3=$ kurang puas ; $4=$ puas ; $5=$ sangat puas.

Hasil uji statistik pengaruh responsiveness perawat terhadap kepuasan pasien menunjukkan nilai signifikan (p) adalah sebesar 0,032 sehingga lebih kecil dari $\alpha=0,05$. Sehingga dapat disimpulkan bahwa terdapat pengaruh responsiveness perawat terhadap kepuasan pasien. Pengujian asumsi juga dilakukan menggunakan aplikasi SPSS.21 dan menunjukkan hasil bahwa memenuhi keenam asumsi regresi linier.

Adanya pengaruh responsiveness perawat dalam melakukan pelayanan keperawatan terhadap kepuasan pasien sesuai dengan salah satu dimensi mutu pelayanan jasa bidang kesehatan atau service 
quality. Responsiveness diartikan sebagai ketanggapan serta kemampuan petugas kesehatan dalam memberikan jasa pelayanan sesuai prosedur, hal ini akan mempengaruhi kepuasan pelanggan. Gambaran komponen responsiveness pada perawat di Instalasi Rawat Inap (IRNA) Rumah Sakit Umum Haji Surabaya sudah tergolong baik. Hal ini dikarenakan hanya terdapat 2 aspek yang mendapat penilaian $\leq 20 \%$ dari pasien dari 5 aspek yang dinilai. Isu masalah dalam komponen responsiveness perawat di Instalasi Rawat Inap (IRNA) Rumah Sakit Umum Haji Surabaya yaitu perawat segera datang ketika pasien membutuhkan mendapat penilaian kurang sebesar $17,39 \%$. Komponen responsiveness atau daya tanggap perawat merupakan komponen terpenting dalam suatu pelayanan karena bersifat sangat dinamis. Penilaian setiap individu terkait aspek cepat atau lambatnya suatu layanan dapat berbeda-beda tergantung dari persepsi setiap individu. Oleh karena itu daya tanggap perawat merupakan suatu hal yang penting dalam mendukung kualitas pelayanan keperawatan. Daya tanggap seorang perawat ketika pasien sedang membutuhkan menunjukkan kehandalan dan kemampuan perawat untuk sigap terhadap berbagai situasi dan kondisi, termasuk sikap dalam menangani keperluan dan keluhan pasien.

Selain itu perawat secara berkala mengunjungi pasien tanpa diminta juga masih mendapat penilaian kurang sebesar $15,94 \%$. Hal ini juga menunjukkan bahwa perawat perhatian dan memberikan pelayanan yang berfokus pada pasien. Perawat secara berkala datang berkunjung untuk mengecek kondisi pasien tanpa diminta dapat menunjukkan rasa kepeduliaan yang tinggi sehingga pasien maupun keluarga pasien merasa puas dan diperhatikan. Sikap perawat yang acuh dan membiarkan pasien menunggu merupakan persepsi yang negatif dalam kualitas pelayanan. Sikap tersebut dapat berpengaruh terhadap kepuasan pasien terhadap jasa yang telah didapatkan.

Dimensi responsiveness adalah penilaian mutu yang paling dinamis karena harapan pelanggan cenderung meningkat sejalan dengan kemajuan teknologi kesehatan. Pelanggan dalam hal ini pasien tentunya akan mengharapkan layanan yang cepat namun tepat, namun kualitas pelayanan yang sebenarnya diberikan atau didapatkan dapat tidak sesuai atau lebih rendah sehingga pelanggan akan memberikan nilai buruk terhadap pengalamannya tersebut. Penilaian tersebut timbul karena tidak atau belum terpenuhinya harapanharapan pelanggan sehingga menyebabkan rasa ketidakpuasan terhadap organisasi penyedia jasa pelayanan kesehatan. Namun sebaliknya, ketika kualitas pelayanan yang diberikan atau didapatkan sama atau bahkan lebih daripada harapan atas pelayanan maka pelanggan akan cenderung merasa puas bahkan loyal.

Hal ini timbul karena organisasi penyedia jasa pelayanan kesehatan mampu memberikan added value yang menimbulkan kesan mendalam bagi pelanggan dan cenderung membuat pelanggan menggunakan kembali jasa dan menceritakan kepada orang lain tentang pengalamannya. Hal ini tentu saja akan berpengaruh positif terhadap keberlangsungan suatu organisasi penyedia jasa pelayanan kesehatan dimana persaingan sangat ketat di era saat ini. Hasil penelitian ini sejalan dengan penelitian yang pernah dilakukan di Instalasi Gawat Darurat (IGD) RSUP Prof. Dr. R. D. Kandou Manado yang menunjukkan bahwa kepuasan pasien berkaitan erat dengan mutu pelayanan keperawatan yang diberikan kepada pasien meliputi salah satunya ketepatan dan kecepatan dalam memberikan pelayanan (Mumu, Kandou and Doda, 2015). Daya tanggap (responsiveness) perawat mempunyai pengaruh dan siginifansi yang positif terhadap kepuasan pasien sehingga semakin baik persepsi pasien terhadap daya tanggap tersebut maka kepuasan akan cenderung tinggi. Namun, apabila persepsi pasien terhadap daya tanggap buruk maka kepuasan juga akan cenderung rendah.

Unsur komunikasi dalam pelayanan jasa kesehatan merupakan salah satu faktor penting. $\mathrm{Hal}$ ini dikarenakan proses komunikasi dalam asuhan keperawatan dapat digunakan sebagai media mengubah perilaku pasien sehingga kesembuhan dapat tercapai. Praktik komunikasi terapeutik perawat dapat diterapkan dalam berbagai elemen pelayanan rumah sakit, namun menjadi sangat penting diperhatikan dan dipraktikkan dalam Instalasi Rawat Inap (IRNA) karena intensistas interaksi antara pasien dengan perawat sangat tinggi.

\section{SIMPULAN}

Kesimpulan dari penelitian yaitu terdapa tpengaruh responsiveness atau daya tanggap perawat dalam melakukan pelayanan keperawatan terhadap kepuasan pasien Instalasi Rawat Inap Rumah Sakit Umum Haji Surabaya. Responden penelitian puas (penilaian pasien $>20 \%$ ) terhadap komponen responsiveness pasien serta hanya terdapat 2 isu yang perlu dilakukan upaya perbaikan guna mempertahankan dan meningkatkan kepuasan pasien. Hasil tersebut didapat setelah dilakukan pengujian statistik regresi linier sederhana terhadap 69 kuesioner yang telah diisi oleh pasien Instalasi Rawat Inap RSU Haji Surabaya yang memenuhi kriteria inklusi penelitian. Oleh karena itu Pihak manajemen Rumah Sakit Umum Haji Surabaya perlu mengadakan pelatihan Sumber Daya Manusia terkait keterampilan komunikasi terapeutik perawat-pasien guna menjaga dan meningkatkan mutu pelayanan, perlu menjadikan komunikasi terapeutik perawat dalam memberikan pelayanan sebagai bagian dari pedoman monitoring dan evaluasi kinerja perawat, serta dapat memberikan reward kepada perawat yang dinilai menjadi role model dalam mempraktikkan komunikasi terapeutik guna mencapai service excellent (kesembuhan dan kepuasan pasien).

Aspek responsiveness atau daya tanggap perawat termasuk kedalam bagian kinerja perawat. Diharapkan kepala ruang Instalasi Rawat Inap 
dapat menerapkan monitoring dan evaluasi dengan pendekatan eksplanatif dengan menjelaskan mengapa suatu hal terjadi (adanya keluhan pasien terhadap responsiveness perawat); mengapa terjadi perubahan (keluhan terhadap responsiveness perawat fluktuatif selama 4 tahun); serta mengapa tidak terjadi perubahan (selama 4 tahun berturutturut aspek responsiveness selalu menduduki urutan pertama jumlah keluhan tertinggi). Inti dari sistem monitoring dan evaluasi menggunakan pendekatan eksplanatif adalah menjawab pertanyaan "mengapa" suatu hal terjadi (Moerdiyanto, 2018)

\section{DAFTAR PUSTAKA}

Damaiyanti, M. (2008) Komunikasi Terapeutik Dalam Praktik Keperawatan. Bandung: Refika Aditama.

Easter, T., Wowor, M. and Pondaag, L. (2017) 'Hubungan Pelayanan Keperawatan Dengan Kepuasan Pasien BPJS Rawat Inap Di Rang Hana RSU Pancaran Kasih GMIM Manado', Jurnal Keperawatan, 5(1), pp. 1-6. Available at:

https://ejournal.unsrat.ac.id/index.php/jkp/arti cle/view/14893/14457.

Eninurkhayatun, B., Suryoputro, A. and Fatmasari, E. Y. (2017) 'Analisis Tingkat Kepuasan Pasien Terhadap Kualitas Pelayanan Rawat Jalan di Puskesmas Duren dan Puskesmas Bergas Kabupaten Semarang Tahun 2017', Jurnal Kesehatan Masyarakat, 5(4), pp. 3342. Available https://ejournal3.undip.ac.id/index.php/jkm.

Khumayrah, U. (2015) Kualitas Pelayanan Rumah Sakit Umum Daerah Daya (Perawatan Interna) Makassar, Repository Unhas. Universitas Hasanuddin Makasar.

Kusmiran, E. (2017) 'Pelatihan Soft Skills Caring Meningkatkan Kualitas Pelayanan Keperawatan dan Kepuasan Pasien di Rumah Sakit Kota Bandung', Jurnal Penelitian dan Pengembangan Pelayanan Kesehatan, 1(2), pp. 72-81. Available at: http://ejournal.litbang.depkes.go.id/index.php /jpppk/article/view/8098/5486.

Luan, M. G. et al. (2018) 'Hubungan Kinerja Perawat dengan Kepuasan Pasien di Ruang Rawat Inap RS Tk. III 04.06.03 Dr. Soetarto Yogyakarta', Jurnal IImiah Keperawatan Indonesia, 1(2), pp. 9-28. Available at: http://www.jurnal.umt.ac.id/index.php.jik.

Moerdiyanto (2018) Teknik Monitoring Dan Evaluasi (Monev) Dalam Rangka Memperoleh Informasi Untuk Pengambilan Keputusan Manajemen, Anzdoc. Available at: https://anzdoc.com/teknik-monitoring-danevaluasi-monev-dalam-rangkamemperoleh.html (Accessed: 20 April 2018).

Mumu, L. J., Kandou, G. D. and Doda, D. V (2015) 'Analisis Faktor-Faktor yang Berhubungan dengan Kepuasan Pasien di Poliklinik Penyakit Dalam RSUP Prof. Dr. R.D. Kandou Manado', JIKMU, 5(4), pp. 1-8. Available at: https://ejournal.unsrat.ac.id/index.php/jikmu/a rticle/view/7460/7530

Paju, W. and Dwiantoro, L. (2018) 'Upaya Meningkatkan Komunikasi Efektif PerawatPasien', Jurnal Keperawatan, 10(1), pp. 2836 Available

at: http://stikeskendal.ac.id/journal/index.php/Ke perawatan/article/view/65.

Potter, P. A. et al. (2013) Fundamentals of Nursing, 8th Edition. 4th edn. Sydney: Elsevier.

RSUD Haji Surabaya (2017) Laporan Kinerja BLUD Rumah Sakit Umum Haji Surabaya Tahun 2017, RSUD Haji Surabaya. Available at: http://rsuhaji.jatimprov.go.id/images/downloa d/LAP KINERJA BLUD TAHUN 2017.pdf.

Supriyanto, S. and Ernawati (2010) Pemasaran Industri Jasa Kesehatan. Yogyakarta: Andi. 